\title{
Hystrix Brachyura Bezoar Characterization, Antioxidant Activity Screening, and Anticancer Activity on Melanoma Cells (A375): A Preliminary Study
}

\author{
$\mathrm{Al}^{\prime}$ aina Yuhainis Firus Khan ${ }^{1,+}{ }^{\dagger}$, Faizah Abdullah Asuhaimi ${ }^{1,+}$, Tara K. Jalal ${ }^{1}$, \\ Fatimah Opeyemi Roheem ${ }^{2}$, Hatim Abdullah Natto ${ }^{1,3}$, Muhammad Farid Johan ${ }^{4}(\mathbb{D}$, \\ Qamar Uddin Ahmed ${ }^{2, *}$ and Ridhwan Abdul Wahab ${ }^{1, *}$ \\ 1 Department of Biomedical Sciences, Kulliyyah of Allied Health Sciences, International Islamic University \\ Malaysia, Kuantan Campus, Bandar Indera Mahkota, Pahang 25200, Malaysia; \\ alainayuhainis@gmail.com (A.Y.F.K.); faizahaa@gmail.com (F.A.A.); tarajalal@ymail.com (T.K.J.); \\ hanatto@uqu.edu.sa (H.A.N.) \\ 2 Department of Pharmaceutical Chemistry, Kulliyyah of Pharmacy, International Islamic University Malaysia, \\ Kuantan Campus, Bandar Indera Mahkota, Pahang 25200, Malaysia; bukolami_fatty@yahoo.com \\ 3 Department of Epidemiology, Faculty of Public Health and Health Informatics, Umm Al-Qura University, \\ Makkah 24381, Saudi Arabia \\ 4 Department of Haematology, School of Medical Sciences, Universiti Sains Malaysia, Kubang Kerian, \\ Kelantan 16150, Malaysia; faridjohan@usm.my \\ * Correspondence: quahmed@iium.edu.my (Q.U.A.); ridhwan@iium.edu.my (R.A.W.) \\ + Equally contributed as first author.
}

Received: 31 December 2018; Accepted: 6 February 2019; Published: 12 February 2019

\begin{abstract}
Porcupine bezoars (PBs) are masses of undigested calcareous concretions formed within the gastrointestinal tract. There are undocumented claims that PBs have antioxidant activity and can treat cancers. However, limited scientific study has been carried out to verify these traditional claims. Hence, this study was conducted to characterize the chemical profile and validate the antioxidant and anticancer activity against melanoma cells (A375). PB extract was initially subjected to Fourier- transform infrared spectroscopy (FTIR), gas chromatography- mass spectrometry (GCMS), total phenolic content (TPC), and total flavonoid content (TFC) analyses. The bioautography of antioxidant assays, namely 2,2'-azino-bis(3- ethylbenzothiazoline- 6-sulphonic acid (ABTS), 2,2-diphenyl-1- picrylhydrazy (DPPH), and $\beta$-carotene was performed. An in vitro A375 cell viability assay, apoptosis assay, cell cycle arrest assay, and gene expression assay were carried out as well. The experimental finding revealed 5,10-diethoxy-2,3,7,8-tetrahydro1H,6H-dipyrrolo[1,2-a:1' $2^{\prime}$-d]pyrazine, ursodeoxycholic acid, and cholest-5-en-3-ol (3 beta)-, carbonochloridate are major compounds detected in PB extract. PB extract has low phenolic content, viz. $698.7 \pm 0.93$ ( $\mu \mathrm{g}$ GAE $/ 5 \mathrm{mg}$ dry weight). The bioautography antioxidant assays revealed a potent antioxidant effect (ABTS $>$ DPPH $>\beta$-carotene), with free radical scavenging activity. Furthermore, PB extract exhibited dose- and time-dependent inhibition of cancer activity on A375 cells due to the exhibition of apoptosis via an intrinsic pathway.
\end{abstract}

Keywords: porcupine bezoar; GCMS; antioxidant assay; apoptosis; traditional medicine 


\section{Introduction}

Cancer has been reported as the second leading cause of mortality worldwide, and is expected to surpass heart disease in the next few years [1]. One recent report has revealed that cancer incidence is predicted to increase to as many as 22 million cases per year [2]. Cancer is characterized by evasion of apoptosis or defective apoptosis mechanisms which in turn lead to uncontrollable development of cells [3]. Most anticancer drugs aim to halt cancer cells from further proliferating and metastasizing to other parts of the body. In spite of great advances in anticancer research, current chemotherapy drugs have been reported to leave cancer survivors with lifelong side effects $[4,5]$. Thus, investigation using a natural product with fewer side effects is crucial.

Antioxidants are the agents that have the ability to prevent, delay or eradicate oxidative stress of a molecule from atmospheric oxygen or reactive oxygen species [6,7]. Antioxidants play an important role in the prevention of various chronic diseases, such as cardiovascular disease, neuronal disease, cataracts, and several types of cancer via the pathophysiology mechanism known as oxidative stress. In this context, there is an increasing interest to search for natural antioxidants present in functional herbs, fruits, and vegetables. Phytoconstituents such as phenolics, carotenoids, anthocyanins, and tocopherol have been found to exert chemo-preventive and cardio-protective effects [8].

In this study, the natural products used for antioxidant and anticancer evaluation is porcupine bezoar (PB) as depicted in Figure 1. PBs are concretions of undigested foreign materials that accumulate and calcify within the gastrointestinal tract of porcupines [9]. The bezoar is a stone-like material and is traditionally believed to exert various medicinal benefits $[10,11]$. The word bezoar itself has origins in Persian (pad = to expel, $\mathrm{zahr}=$ poison or antidote) [11]. Bezoar was valued as gem and as a noble metal. A review on the importance of bezoar has revealed that the oriental bezoars found in monkeys and porcupines (Lapis bezoar orientalis) were considered the most expensive [12-14]. Porcupine bezoars are generally composed of three concentric layers made up of vegetal matter [9]. Traditionally, people have used bezoars to treat several deadly diseases such as cholera, plague, smallpox, and measles, and as an antidote for poisons of different origins [7-9]. Due to traditional claims of medicinal benefits of porcupine bezoars and its rarity, traders tend to sell it at implausibly high prices. Moreover, there are undocumented traditional claims in several parts of Malaysia that porcupine bezoars can treat cancers and possess high antioxidant activity. Despite these undocumented traditional claims, there is limited information on the antioxidant and anticancer properties of porcupine bezoar. Therefore, the objective of this study was to characterize the PB chemical profile, investigate its antioxidant and anticancer properties to verify its traditional claim, and to explore its medicinal potential.

a)

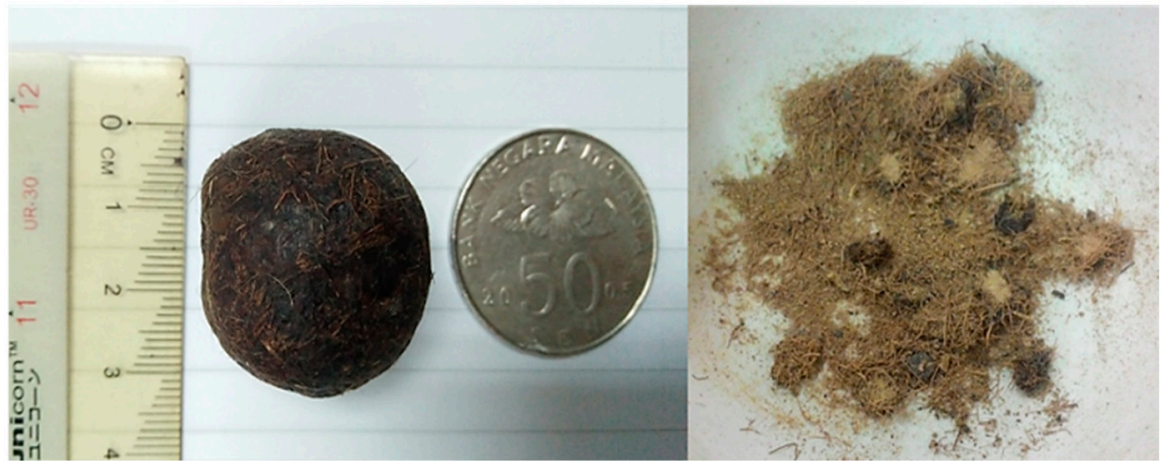

Figure 1. The porcupine bezoar (PB) used in this study. (a) PB with a Malaysian 50 sen coin and scale as size reference. (b) A PB after being crushed consists of a mixture of rough powder and undigested fiber. 


\section{Materials and Methods}

\subsection{Chemicals and Reagents}

Methanol, Folin-Ciocalteu phenol reagent, and gallic acid were purchased from Honeywell (Charlotte, NC, USA). Quercetin, 1, 1-diphenyl-2-picrylhydrazyl radical (DPPH), trichloroacetic acid, and thin layer chromatography (TLC) plates were purchased from Sigma-Aldrich (St. Louis, $\mathrm{MO}$, USA). Aluminium chloride hexahydrate $\left(\mathrm{AlCl}_{3} \cdot 6 \mathrm{H}_{2} \mathrm{O}\right)$, sodium bicarbonate $\left(\mathrm{Na}_{2} \mathrm{CO}_{3}\right)$, sodium phosphate dibasic $\left(\mathrm{Na}_{2} \mathrm{HPO}_{4}\right)$, sodium phosphate monobasic $\left(\mathrm{NaH}_{2} \mathrm{PO}_{4}\right)$, and ABTS [2,2'-azinobis (3-ethylbenzothiazoline)-6-sulfonic acid] diammonium salt were purchased from Roche, Basel, Switzerland. Human melanoma (A375) and normal human dermal fibroblast (NHDF) were obtained from American Type Culture Collection (ATCC; Manassas, VA, USA). Cells were grown in complete growth medium (CGM) which was made of Dulbecco's modified Eagle medium (DMEM) (Nacalei Tesque, Kyoto, Japan) supplemented with 10\% fetal bovine serum (Nacalei Tesque, Kyoto, Japan) and 1\% penicillin-streptomycin (Nacalei Tesque, Kyoto, Japan). Phosphate-buffered saline (PBS) (Gibco, Waltham, MA, USA) was used for cell washing. For analyzing apoptosis and cell cycle, Nexin reagent (Merck Millipore, Burlington, MA, USA) and cell cycle reagent (Merck Millipore, Burlington, MA, USA) were used, respectively. For the mRNA expression analysis, InnuPREP DNA/RNA mini kit (Analytik Jena, Jena, Germany), SensiFAST cDNA synthesis kit (BIOLINE, Memphis, TN, USA), SensiFAST SYBR $^{\circledR}$ No-ROX Kit (BIOLINE, Memphis, TN, USA), and primer (Integrated DNA technologies, Singapore) were used. 5-Fluorouracil (5-FU) (Sigma-Aldrich, St. Louis, MO, USA), a standard anticancer drug, was used as a positive control.

\subsection{Porcupine Bezoar Extract Preparation}

The investigation using Hystrix brachyura bezoar was performed with the permission from the Malaysian government authority viz. Department of Wildlife and National Parks, Malaysia, for academic and research purposes (JPHL\&TN (IP): 100-34/1.24 Jld 8). The PB (9.26 g) was crushed into a powdered form using mortar and pestle. Subsequently, $1 \mathrm{~g}$ of powdered PB was extracted using deionized water with 1:20 ratio for 30 min using ultrasonication method to get PB aqueous extract [15]. The supernatant was filtered and freeze-dried obtained PB aqueous extract in powdered form (250 mg, 25\%). The dry powdered form of PB aqueous extract was then subjected to chemical profile characterization, bioautography antioxidant assay, and anticancer activity evaluation. For anticancer activity, PB aqueous extract was prepared into stock solution $(2.0 \mathrm{mg} / \mathrm{mL})$ and further diluted with CGM or DMEM accordingly. On the other hand, the positive control (5-FU) was prepared by dissolving in DMSO, before making it into stock solution $(1.0 \mathrm{mg} / \mathrm{mL})$ with CGM and diluted further accordingly.

\subsection{Fourier-Transform Infrared Spectroscopy Analysis Of Porcupine Bezoar}

A Fourier-transform infrared (FTIR) spectrometer (Perkin Elmer Inc., Waltham, MA, USA) was used for the functional groups analysis. Prior to FTIR analysis, the PB aqueous extract was thoroughly freeze-dried to ensure an absence of water molecule. A small mass of PB aqueous extract was placed on the diamond crystal and the spectra were collected in wave number region of $400-4000 \mathrm{~cm}^{-1} \mathrm{at} \mathrm{a}^{-}$ resolution of $4 \mathrm{~cm}^{-1}$. The data were processed using PerkinElmer Spectrum (version 10.03.09) software (PerkinElmer, Waltham, MA, USA).

\subsection{Gas Chromatography Mass Spectroscopy (GCMS) Profile Analysis of Porcupine Bezoar}

The aim of this assay was to determine the chemical profile of PB aqueous extract. The PB aqueous extract was derivatized as described previously [16]. GCMS-TQ8030 linked to a GCMS-QP 2010 Plus Shimadzu gas chromatograph equipped with a capillary column DB-5 $(0.25 \mu \mathrm{m}$ thickness $\times 0.25 \mathrm{~mm}$ diameter $\times 30 \mathrm{~mm}$ length) was used for compound identification. Helium $(1.0 \mathrm{~mL} / \mathrm{min})$ was used as the carrier gas (Shimadzu, Japan). The instrument was operated in electron impact mode at ionization voltage $(70 \mathrm{eV})$, injector temperature $\left(250{ }^{\circ} \mathrm{C}\right)$, and detector temperature $\left(280^{\circ} \mathrm{C}\right)$. The starting oven 
temperature was set at $50{ }^{\circ} \mathrm{C}$ and held for $5 \mathrm{~min}$. This temperature was then programmed to $150{ }^{\circ} \mathrm{C}$ at $5^{\circ} \mathrm{C}$ per min and held for $5 \mathrm{~min}$. Finally, the temperature was programmed to $300^{\circ} \mathrm{C}$ for $5 \mathrm{~min}$ at a rate of $5^{\circ} \mathrm{C}$ per min. The compound identification from the spectral data was based on the available mass spectral records in National Institute of Standards and Technology database.

\subsection{Total Phenol Content (TPC)}

Folin-Ciocalteu's method was modified and adapted to the 96-well plate assay as described by previously for the quantification of total phenolic content [17]. Mixtures of 25\% (w/v) Folin-Ciocalteu's reagent and $75 \%(\mathrm{w} / \mathrm{v})$ sodium carbonate were prepared. Then, $50 \mu \mathrm{L}$ of both mixtures were mixed with $10 \mu \mathrm{L}$ of sample $(5 \mathrm{mg} / \mathrm{mL})$ and incubated for $45 \mathrm{~min}$ at room temperature. Absorbance was set at $765 \mathrm{~nm}$ using a Tecan microplate reader (Infinite ${ }^{\circledR} 200$ PRO, Männedorf, Switzerland) against blank. All assays were carried out at least in triplicate. The results were expressed as microgram gallic acid (GAE) equivalent per gram dry weight basis of the fresh sample (mg GAE/g dw basis).

\subsection{Total Flavonoid Content (TFC)}

Total flavonoid content was determined through modified method using 96-well plate as described earlier [17]. An aliquot of $(10 \mu \mathrm{L})$ of sample $(5 \mathrm{mg} / \mathrm{mL})$ was mixed with $90 \mu \mathrm{L}$ of $2 \%(\mathrm{w} / \mathrm{v})$ aluminum chloride and incubated for $10 \mathrm{~min}$ at room temperature. The absorbance was set at $415 \mathrm{~nm}$ and the mixture was read using microplate reader (Tecan Infinite ${ }^{\circledR} 200$ PRO) against blank. All tests were performed in triplicate. The data were expressed as microgram quercetin (QE) equivalent per gram dry weight basis of fresh sample (mg QE/g dw basis).

\subsection{Rapid Screening of Antioxidant by Dot-Blot Assay}

\subsubsection{DPPH Dot-Blot Assay}

Sixteen grids of TLC plates were separately loaded with sample (PB aqueous extract) and standard (ascorbic acid) in decreasing concentrations $(5-0.153 \mathrm{mg} / \mathrm{mL}$ ) via two-fold serial dilution. The plate was left to completely dry at room temperature. Both plates were dipped for $10 \mathrm{~s}$ in $0.05 \%$ of DPPH in methanol. Excess solution was removed with tissue paper and the plate was air dried. After $30 \mathrm{~min}$. result was taken. Stained silica layer revealed a purple background with white/yellow spots at the location where radical-scavenger capacity presented. The intensity of the white/yellow color depends upon the amount and nature of radical scavenger present in the sample [18].

\subsection{2. $\mathrm{ABTS}^{+}$Dot-Blot Assay}

The 2,2'-azino-bis (3-ethylbenzothiazoline-6-sulfonic acid) diammonium salt radical cation $\left(\mathrm{ABTS}^{+}\right)$is a stable free radical frequently used for estimating the total antioxidant capacity of natural products. $\mathrm{ABTS}^{+}$solution was prepared by mixing $7 \mathrm{mM}$ ABTS stock solution with $2.45 \mathrm{mM}$ potassium persulfate with ratio 1:1 (v/v) leaving the mixture in dark at room temperature for $16 \mathrm{~h} \mathrm{[19].} \mathrm{Dried} \mathrm{TLC}$ plates with pre-loaded sample (PB aqueous extract) and standard (ascorbic acid) were dipped in $\mathrm{ABTS}^{+}$solution exhibited green background with white or pink spot indicated the presence of radical scavengers in PB aqueous extract [20].

\subsection{3. $\beta$-Carotene Dot-Blot Assay}

Pre-loaded TLC plates with sample (PB aqueous extract) and standard (quercetin) were prepared and left to dry completely. The TLC plates were dipped in $0.05 \%$ solution of $\beta$-carotene in chloroform and exposed to sunlight for 2-3 hours or until the yellow background bleached [20]. Active compound will remain in yellow with white background. 


\subsection{Cell Culture Maintenance}

Human malignant melanoma cells (A375) were maintained in complete growth medium (CGM) supplemented with $89 \%$ of Dulbecco's modified eagle medium (DMEM), $10 \%$ fetal bovine serum and $1 \%$ of penicillin streptomycin antibiotic at $37{ }^{\circ} \mathrm{C}$ and $5 \% \mathrm{CO}_{2}$ humidified atmosphere.

\subsection{Cytotoxicity Assay of Porcupine Bezoar on Cancer Cell and Normal Cell}

This assay was performed to determine the median inhibition concentration on cancer cell of A375. Cell viability to determine $50 \%$ inhibitory concentration $\left(\mathrm{IC}_{50}\right)$ and proliferation assay were evaluated using Promega CellTiter $96{ }^{\circledR}$ AQueous Non-Radioactive Cell Proliferation (Promega, Madison, WI, US) assay as recommended by the manufacturer. In determining $\mathrm{IC}_{50}$, cells were seeded at $4.0 \times 10^{2}$ cells $/ \mathrm{mL}$ and treated with PB extract with serial concentrations of $3.9-1000 \mu \mathrm{g} / \mathrm{mL}$ in a 96-well plate before incubation for $72 \mathrm{~h}$. Then, $10 \mu \mathrm{L}$ of MTS reagent were added in each well and incubated for $3 \mathrm{~h}$ before measuring at $490 \mathrm{~nm}$ using a microplate reader. The $\mathrm{IC}_{50}$ values for $\mathrm{PB}$ aqueous extract and 5-FU were calculated using Graphpad Prism 6. Further test for the proliferation assay over time (24, 48, 72 and $95 \mathrm{~h})$ used untreated (UT) cells as negative control and 5-fluorouracil as positive control. Additionally, the $\mathrm{IC}_{50}$ of $\mathrm{PB}$ aqueous extract was evaluated on NHDF with UT and 5-FU as controls.

\subsection{Cell Cycle Arrest Assay}

Cell cycle assay was performed to determine whether $\mathrm{PB}$ aqueous extract has the ability to induce cell arrest in A375 cells and through which phase. Grown cells were treated with PB aqueous extract at $\mathrm{IC}_{50}$ for $72 \mathrm{~h}$. All cells from the well were collected and prepared in triplicate. The cells were fixed with cold ethanol for $2 \mathrm{~h}$ and stained with cell cycle kit according to the manufacturer's instructions. Cells were analyzed using guava flow cytometer (Luminex, Austin, TX, USA).

\subsection{Apoptosis Assay}

Apoptosis Annexin V/7AAD assay was performed to determine the apoptosis distribution. A375 cells were treated with PB aqueous extract at $\mathrm{IC}_{50}$ for $72 \mathrm{~h}$. All cells from the well were harvested and prepared in triplicate. For apoptosis analyses, cells were stained using Nexin reagent and analyzed using guava flow cytometer following the manufacturer instruction. Distribution of early and late apoptotic cells after exposure with PB aqueous extract was reported in a dot plot graph.

\subsection{Real Time Quantitative PCR (RT-qPCR) Analysis}

The aim of this assay was to quantify the mRNA expression of mRNA of targeted primers related to apoptosis, cell cycle arrest and metastasis. Total RNA was extracted from PB aqueous extract-treated or untreated A375 cells after $72 \mathrm{~h}$ using RNA extraction kit according to the manufacturer's instructions. The RNA's quality and integrity were assessed before quantification process. The complementary DNA (cDNA) was prepared using cDNA synthesis kit according to manufacturer's instructions. Subsequently, $200 \mathrm{ng}$ of RNA template were synthesized into cDNA and later diluted in the experiments. The primers were chosen from the National Centre for Biotechnology Information (NCBI) database with a melting temperature $(\mathrm{Tm})$ of $59-65^{\circ} \mathrm{C}$. Amplicon size was $70-150$ bases. Forward and reverse primers spanning exon-exon junctions were selected to avoid amplification of genome sequences. PCR amplifications were performed using SYBR green in CFX96 Touch ${ }^{\mathrm{TM}}$ Real-Time PCR (Bio-Rad, Hercules, CA, USA). Annealing temperature was optimized using gradient temperature setting. Melting curves were analyzed to ensure amplification specificity and null primer-dimer formation. Primer PCR efficiency was evaluated using serial dilutions of cDNA sample $(1: 10,1: 100,1: 1,000,1: 10,000$, and 1:100,000) in CFX Manager Software. The amplification efficiency (E) and correlation coefficients (R2) of the standard curve ranged from $93.0 \%$ to $114.7 \%$ and 0.984 to 0.998, respectively. Details information about the primers are attached in supplementary Table S1. 
The amplifications were done by following the conditions viz., $2 \mathrm{~min}$ at $50{ }^{\circ} \mathrm{C}, 10 \mathrm{~min}$ at $95^{\circ} \mathrm{C}$, and 45 cycles of $15 \mathrm{~s}$ at $95^{\circ} \mathrm{C}$ and $1 \mathrm{~min}$ at $60^{\circ} \mathrm{C}$. Results were analyzed using CFX Manager Software based on the threshold cycle (CT) values. Glyceraldehyde 3-phosphate dehydrogenase (GAPDH) and $\beta$-actin (ACTB) were used as reference genes. The genes used, and the nucleotide sequences are summarized in Table 1.

Table 1. Primer sequences used in quantitative polymerase chain reaction analysis.

\begin{tabular}{|c|c|c|}
\hline Primer & Forward Sequence $5^{\prime}$ to $3^{\prime}$ & Reverse Sequence $5^{\prime}$ to $3^{\prime}$ \\
\hline $\mathrm{ACTB}$ & F-CGGCGCCCTATAAAACCCA & R-ATCATCCATGGTGAGCTGGC \\
\hline GAPDH & F-GACAGTCAGCCGCATCTTCT & R-GCGCCCAATACGACCAAATC \\
\hline $\mathrm{BAX}$ & F-GAACCATCATGGGCTGGACAT & R-ATGGTCACGGTCCAACCACC \\
\hline BCL2 & F-ATGTGTGTGGAGAGCGTCAA & R-GGGCCGTACAGTTCCACAAA \\
\hline CYTOCHROME C & F-CCCAAGAAGTACATCCCTGGAAC & R-GGCAGTGGCCAATTATTACTCA \\
\hline CAS 3 & F-TGGTTTGAGCCTGAGCAGAG & R-TGGCAGCATCATCCACACAT \\
\hline CAS 9 & F-TGACCCCAGAATTGACCCTG & R-AAGGATTCGCTCTTGCGTC \\
\hline
\end{tabular}

\subsection{Statistical Analysis}

All values were presented as mean \pm SD of triplicate from three different experiments $(n=3)$. A one-way analysis of variance (ANOVA) was performed using the Prism statistical software package (GraphPad Software, San Diego, CA, USA). This study used the Dunnet test as follow-up test of ANOVA which compared PB aqueous extract and 5-FU with UT. Differences between PB aqueous extract treated and UT were considered statistically significant at $p<0.01$.

\section{Results}

\subsection{Porcupine Bezoar Characterization}

The chemical characteristic of the PB aqueous extract is presented in Figure 2a for FT-IR and Figure $2 b$ for GCMS. The FT-IR spectrum depicted bonds relevant to hydrogen bonded O-H stretch vibrational bands at 3100 and $3690 \mathrm{~cm}^{-1}$ which might belong to carboxylic, alcohol, or phenol groups. Furthermore, a medium sp3 $\mathrm{C}-\mathrm{H}$ stretch indicating an alkane group was determined at vibrational bands of 2800 and $3000 \mathrm{~cm}^{-1}$. Stretching weak alkene $(C=C)$ and double medium carbonyl $(C=O)$ were detected at vibrational bands of $1500-1580 \mathrm{~cm}^{-1}$ and $1580-1800 \mathrm{~cm}^{-1}$, respectively. Moreover, in the fingerprint region, a hydroxyl group was observed at $1400 \mathrm{~cm}^{-1}, \mathrm{C}-\mathrm{O}$ stretching at $1200 \mathrm{~cm}^{-1}$, and $\mathrm{C}=\mathrm{C}$ bending at $1050 \mathrm{~cm}^{-1}$.

Moreover, the PB extract was subjected to GC-MS analysis to evaluate PB extract chemical profile. The GC-MS retention time, \% area peak, molecular formula and its similarity index are given in Table 2 . The findings from Figure $2 \mathrm{~b}$ and Table 2 show the major compounds detected are 5,10-diethoxy-2,3,7,8-tetrahydro-1H,6H-dipyrrolo [1, 2-a: 1' , 2'-d] pyrazine (11.28\%), ursodeoxycholic acid (8.63\%), cholest-5-en-3-ol (3.beta.)-, carbonochloridate (5.09\%), and pentadecyl acrylate (4.10\%). Details of each compound's mass spectrum and structure are attached in supplementary Figure S1.

\subsection{Total Phenolic Content and Total Flavonoid Content of Porcupine Bezoar}

The total phenolic content (TPC) values were quantified based on the linear equation obtained from the gallic acid standard calibration curve. The TPC values were expressed as gallic acid equivalents (mg GAE/5 mg samples) at $698.7 \pm 0.93$. On the other hand, the total flavonoid content (TFC) was quantified based on the linear equation obtained from the quercetin standard calibration curve, and TFC values were expressed as the quercetin equivalent (mg QE/5 mg dry sample) which was -0.009 (mg/5 mg dry weight). The standard curves for TPC and TFC are attached in supplementary Figures S2 and S3. 
Table 2. GC-MS profile analysis of PB aqueous extract.

\begin{tabular}{|c|c|c|c|c|c|}
\hline Peak & $\begin{array}{l}\text { Retention } \\
\text { Time }\end{array}$ & Area $(\%)$ & $\begin{array}{l}\text { Molecular } \\
\text { Formula }\end{array}$ & Compound & $\begin{array}{l}\text { Similarity } \\
\text { Index }\end{array}$ \\
\hline 1 & 9.784 & 2.91 & $\mathrm{C}_{12} \mathrm{H}_{26} \mathrm{O}$ & 1-Dodecanol & 97 \\
\hline 2 & 12.552 & 4.10 & $\mathrm{C}_{18} \mathrm{H}_{34} \mathrm{O}_{2}$ & Pentadecyl acrylate & 91 \\
\hline 3 & 15.577 & 11.28 & $\mathrm{C}_{14} \mathrm{H}_{22} \mathrm{~N}_{2} \mathrm{O}_{2}$ & $\begin{array}{c}\text { 5,10-Diethoxy-2,3,7,8-tetrahydro- } 1 \mathrm{H}, 6 \mathrm{H} \text {-dipyrrolo } \\
{\left[1,2 \text {-a: } 1^{\prime}, 2^{\prime} \text {-d] pyrazine }\right.}\end{array}$ & 81 \\
\hline 4 & 16.11 & 2.32 & $\mathrm{C}_{15} \mathrm{H}_{30} \mathrm{O}_{2} \mathrm{~S}$ & Lauryl 3-mercaptopropionate & 93 \\
\hline 5 & 17.566 & 3.50 & $\mathrm{C}_{18} \mathrm{H}_{36} \mathrm{O}_{2}$ & Stearic acid & 93 \\
\hline 6 & 17.812 & 2.00 & $\mathrm{C}_{16} \mathrm{H}_{33} \mathrm{NO}$ & Palmitamide & 94 \\
\hline 7 & 20.508 & 2.12 & $\mathrm{C}_{18} \mathrm{H}_{37} \mathrm{NO}$ & Octadecanamide & 93 \\
\hline 8 & 22.223 & 1.04 & $\mathrm{C}_{19} \mathrm{H}_{38} \mathrm{O}_{4}$ & Glyceryl 2-palmitate & 81 \\
\hline 9 & 25.542 & 1.63 & $\mathrm{C}_{21} \mathrm{H}_{42} \mathrm{O}_{4}$ & Octadecanoic acid, 2,3-dihydroxypropyl ester & 82 \\
\hline 10 & 26.755 & 5.09 & $\mathrm{C}_{28} \mathrm{H}_{45} \mathrm{ClO}_{2}$ & Cholest-5-en-3-ol (3 beta)-, carbonochloridate & 81 \\
\hline 11 & 29.316 & 8.63 & $\mathrm{C}_{24} \mathrm{H}_{40} \mathrm{O}_{4}$ & Ursodeoxycholic acid & 82 \\
\hline
\end{tabular}

a)

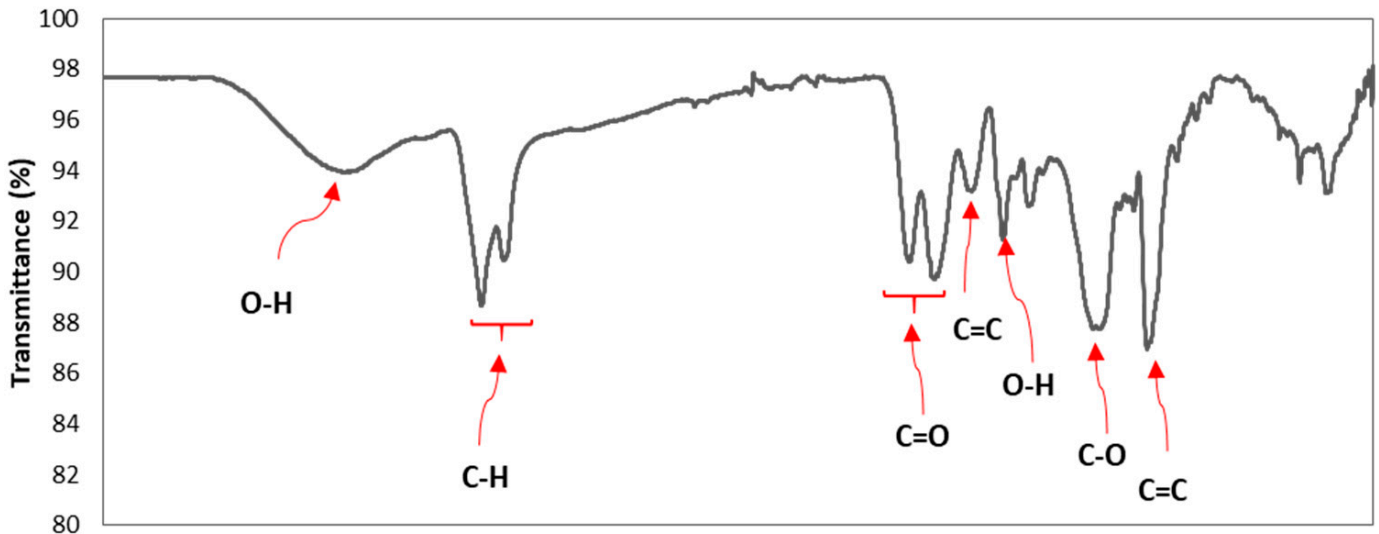

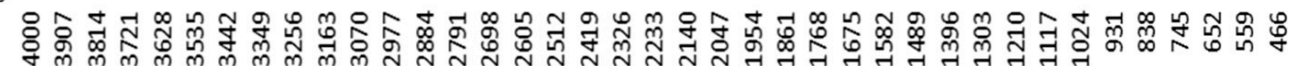

b)

Wavelength $\mathrm{cm}^{-1}$

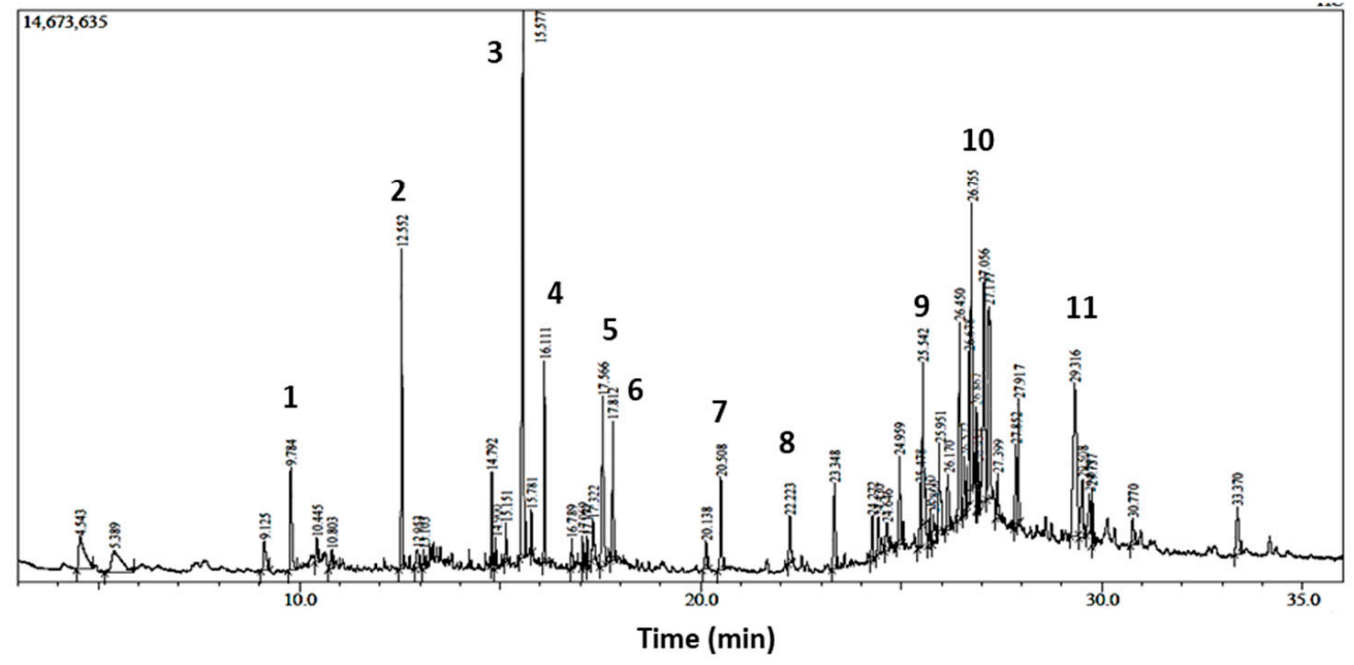

Figure 2. Porcupine bezoar chemical characterization. (a) The FTIR spectrum with its functional group detected. (b) The GCMS chromatogram of aqueous extract. 
The aqueous PB extract was subjected to dot-blot antioxidant assay namely ABTS, DPPH and $\beta$-carotene. As depicted in Figure 3, for ABTS, the greenish area indicates no antioxidant activity while the bright white area indicates free radical scavenger. On the other hand, for DPPH the purple area on the plate indicates no free radical scavenging activity and the yellow area indicates antioxidant activity. As for the $\beta$-carotene assay, the brownish area indicates free radical scavenging of $\beta$-carotene. The dot-blot TLC plate showed the effect of $\mathrm{PB}$ aqueous extract on scavenging free radicals from serial concentration tested from 5.0 to $0.039 \mathrm{mg} / \mathrm{mL}$. For the ABTS assay, the $5.0 \mathrm{mg} / \mathrm{mL}$ of PB extract showed to have similar dot-blot intensity with the fifth dilution $(\sim 0.3125 \mathrm{mg} / \mathrm{mL})$ of the standard. For the DPPH assay, the highest concentration tested had similar dot-blot intensity with the seventh dilution $(\sim 0.078 \mathrm{mg} / \mathrm{mL})$ of standard. On the other hand, $\beta$-carotene assay, the brownish intensity was similar with the eighth dilution $(\sim 0.039 \mathrm{mg} / \mathrm{mL})$. The screening dot-blot antioxidant assay revealed PB aqueous extract to have ABTS $>$ DPPH $>\beta$-carotene free radical scavenging activity.
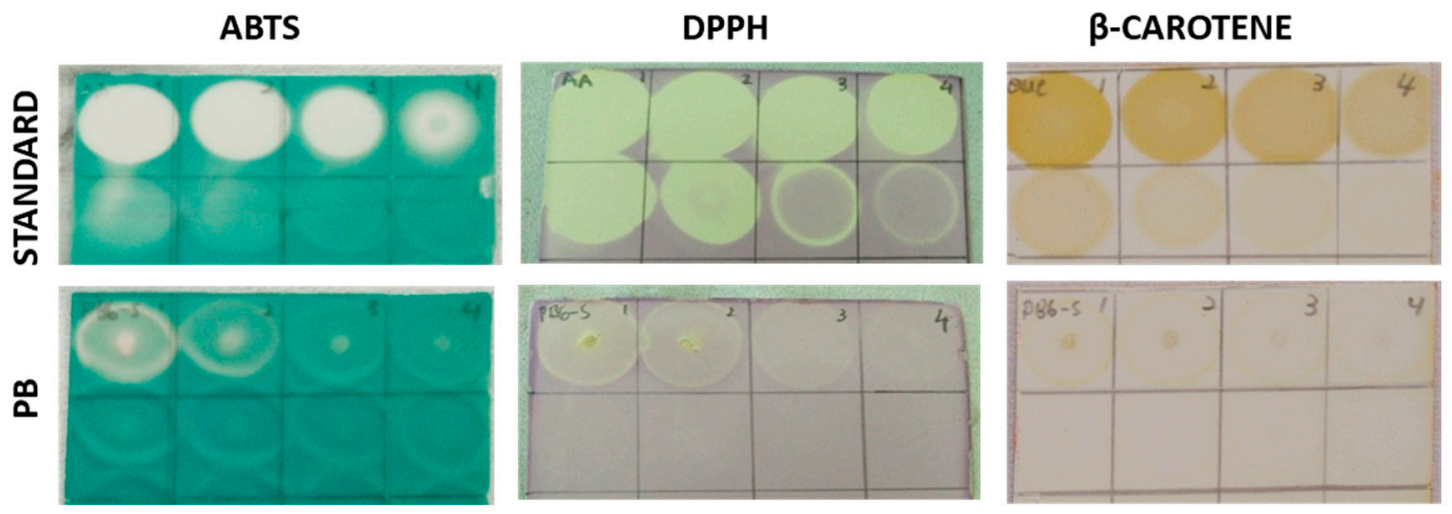

Figure 3. Dot-blot antioxidant of $\mathrm{PB}$ aqueous extract. Representative of dot-blot image of PB aqueous extract dilution series for ABTS, DPPH, and $\beta$-carotene bleaching antioxidants assay with ascorbic acid and quercetin as standard, respectively. For each assay, the initial concentration tested was $5.0 \mathrm{mg}$ and further diluted in a 1:2 fold ration. $(n=3)$.

\subsection{Anticancer Activity of Porcupine Bezoar Aqueous Extract on Melanoma Cell (A375)}

The cytotoxic effect of PB aqueous extract was evaluated on human melanoma, A375 cells. The A375 cells were subjected to various concentrations of PB aqueous extract for 72 hours and analyzed using MTS assay. The PB extract demonstrated a dose-dependent inhibitory effect on A375 cells growth. The $\mathrm{IC}_{50}$ values of $\mathrm{PB}$ are reported together with 5-FU in Figure 4a. The cytotoxic effect of $\mathrm{IC}_{50}$ of $\mathrm{PB}$ was further analyzed through proliferation assay. The result in Figure $4 \mathrm{~b}$ demonstrated $\mathrm{PB}$ aqueous extract inhibits cell growth significantly across time incubation $(24,48$, and $72 \mathrm{~h})$ when compared to UT. Figure $4 \mathrm{c}$ presents the effect of $\mathrm{IC}_{50}$ of PB aqueous extract on NHDF. The graph revealed $\mathrm{PB}$ extract did not cause significant toxicity effect on cells viability as compared to 5-FU which caused significant cell viability reduction. Figure $4 \mathrm{~d}$ shows that A375 cells treated with the PB aqueous extract demonstrated reduction of cells density compared to UT. Additionally, there were presence of cells debris in PB-treated cells. On the other hand, the untreated cells showed intact morphology of A375. Moreover, the morphology of NHDF supported the finding in Figure 4c as the morphology of PB aqueous extract-treated cells shows intact morphology of NHDF cells similarly to UT NHDF. 
a)

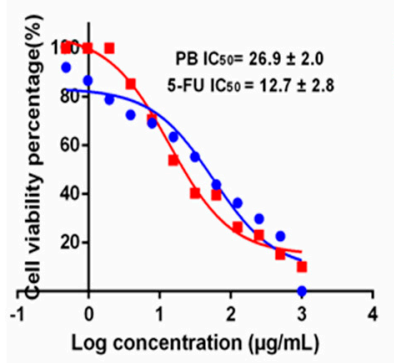

d)

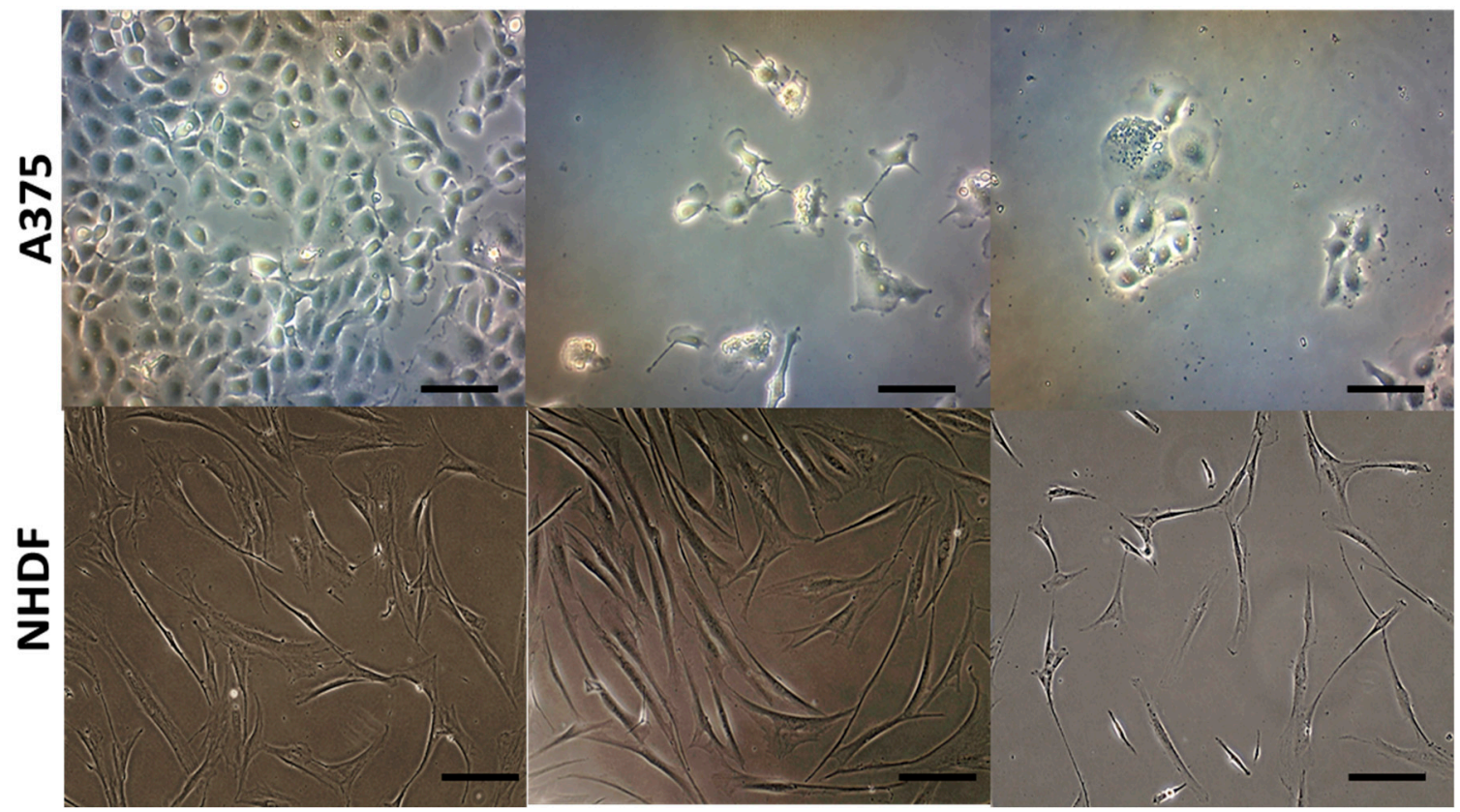

Figure 4. The effect of PB aqueous extract on A375 cells viability. (a) Median concentration of A375 treated with $\mathrm{PB}$ aqueous extract and 5-fluorouracil (5-FU). Graph shown are after the exposure with treatment for $72 \mathrm{~h}$. $\mathrm{IC}_{50}$ is presented in mean $\pm \mathrm{SD}(n=3)$. (b) Anti-proliferative effect of PB aqueous extract at 24, 28, 72, and $96 \mathrm{~h}$ with untreated cells (UT) and 5-FU as controls. (c) Cytotoxic effect of median concentration on normal human dermal fibroblast (NHDF) cells at 72-h incubation. (d) Image of A375 and NHDF cells upon treatment with PB aqueous extract, UT, and 5-FU for $72 \mathrm{~h}$. Bar graph = $25 \mu \mathrm{m} .{ }^{*}$ indicates $p<0.01$.

\subsection{Porcupine Bezoar Aqueous Extract Induced Apoptosis on Melanoma Cell}

Subsequently, the study explored the connection of A375 cell growth inhibition with cell cycle arrest. The PB aqueous extract treated A375 cells were exposed for $72 \mathrm{~h}$ and analyzed the cell cycle distribution using flow cytometry. Figure $5 \mathrm{a}$,c, presents interesting findings as $\mathrm{PB}$ aqueous extract showed no evidence of inducing cells arrest in A375. The PB aqueous extract treated cells showed similar proportion of cells population with UT in all cell cycle phase. On the other hand, 5-FU treated cells showed cells arrest in G1/G0 phase where it can be seen that the cells accumulate in G1/G0 with reduction in $S$ phase and $\mathrm{G} 2 / \mathrm{M}$ phase. 
a)

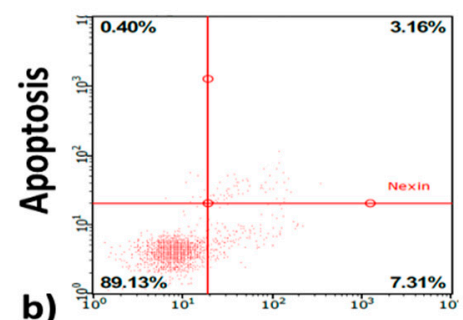

b)

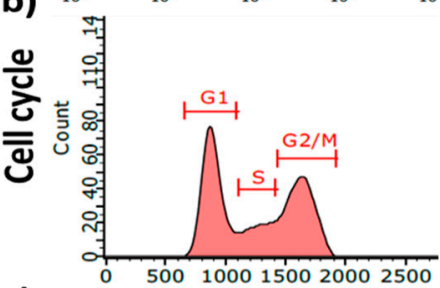

c)

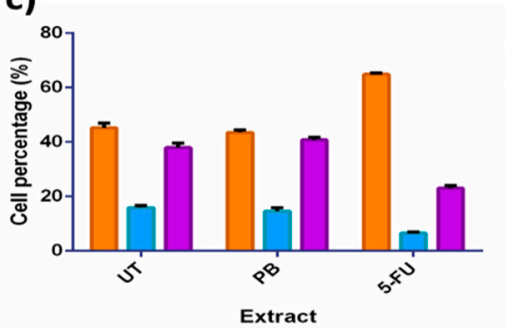

PB
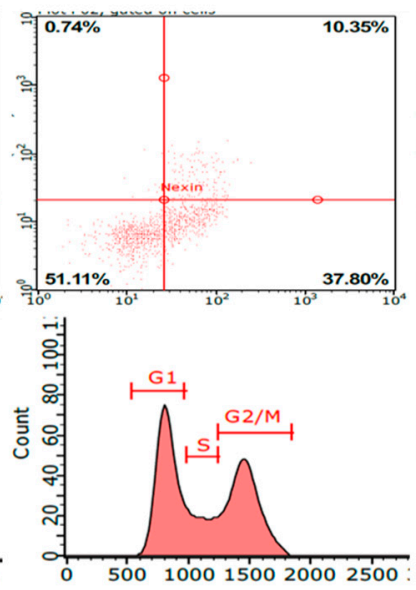

d)

5-FU
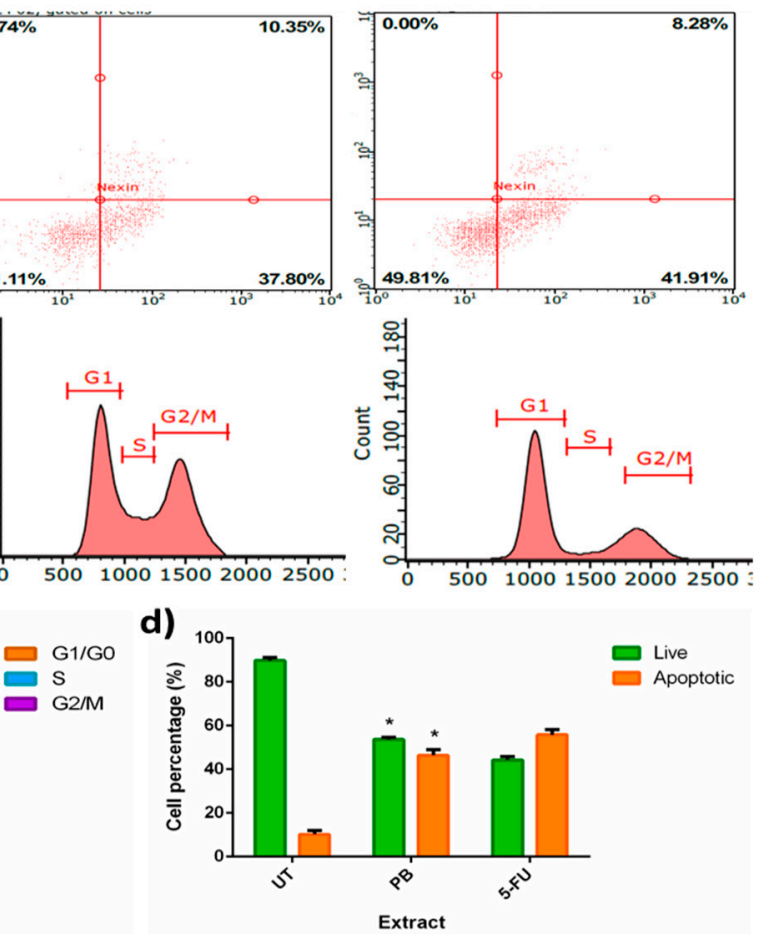

$\square$ Live Apoptotic

e)

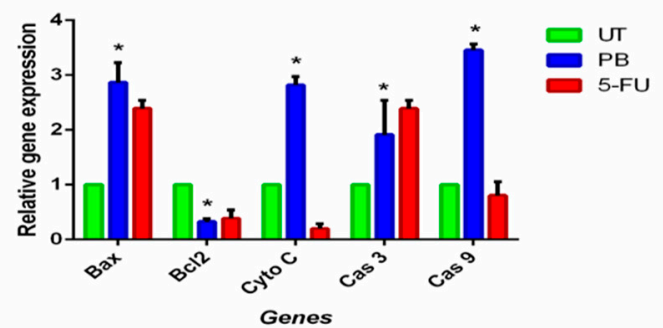

Figure 5. (a) Representation of DNA histogram of PB-treated cells, with UT and 5-FU as control. The analysis was after $72 \mathrm{~h}$ of incubation. DNA histograms displays cell cycle phases of treated cells, namely G1/G0, S, and G2/M ( $n=3)$. (b) Representation of dot plot distribution of early and late apoptosis of A375 cells upon exposure with PB for $72 \mathrm{~h}$ with UT and 5-FU as control, $(n=3)$. (c) The proportion of cells according to cell cycle phase are presented in percentage mean $\pm \operatorname{SD}(n=3)$. (d) The proportion percentages of apoptotic (early and late apoptosis) and live cells are presented as percentage mean $\pm \mathrm{SD}(n=3)$. (e) The mRNA expression of apoptosis targeted genes is presented as relative gene expression mean $\pm \mathrm{SD}(n=3)$. The modulations of mRNA expressions levels of targeted genes are expressed as relative gene expression based on the calculation using GAPDH and $\beta$-actin as the reference gene, assigning the ratio in untreated cells as $1 .{ }^{*}$ indicates $p<0.01$.

Further analysis was carried out to evaluate whether PB aqueous extract inhibits the cells growth of A375 cells due to apoptotic activity. The PB aqueous extract treated cells were stained with Annexin V/7AAD. As presented in Figure 5b,d, PB aqueous extract induced apoptosis resulting in significant distribution of early apoptosis in PB aqueous extract treatment for $72 \mathrm{~h}$. The dot-plot graph in Figure $5 \mathrm{~b}$ demonstrates that $\mathrm{PB}$ aqueous extract induced early apoptosis by $37.80 \%$ and late apoptosis by $10.35 \%$ compared to UT, at $7.31 \%$ and $3.16 \%$, respectively. Figure $5 \mathrm{~d}$ reveals bar graph proportions of apoptotic cells (including early and the late apoptosis) and live cells which are $51.11 \%$ and $48.89 \%$, respectively. To understand the mechanism of apoptosis at molecular level, qPCR experiment was performed on key genes viz., Bax (pro-apoptosis), Bcl2 (anti-apoptosis), cyto $C$, cas 3, and cas 9. Figure 5e depicts that PB aqueous extract down-regulated Bcl2 (0.3 fold), and up-regulated Bax (2.8 fold), cyto C ( 2.8 fold), cas 3 (1.9 fold), and cas 9 (3.4 fold). The mRNA expression finding indicated PB aqueous extract induced 
apoptosis via the mitochondria apoptosis pathway. As for 5-FU, it can be seen that apoptosis occurred, as Bcl2 (0.4 fold) was down-regulated while Bax (2.4 fold), and cas 3 (2.5 fold) were up-regulated. However, the pathway of 5-FU apoptosis could not be determined.

\section{Discussion}

Porcupine bezoars have been used for past centuries for its medicinal benefits, however the information about its properties are still limited. Hence, the current study was performed to investigate the chemical characterization of $\mathrm{PB}$, and evaluate its antioxidant activity and anticancer activity on melanoma cells. In the current study, the extraction method of PB was carried out using sonication procedure. As mentioned in [21], the sonication mechanism diffuses the solid area of the sample into the solvent. By forming cavitation bubbles that assist to break down the plant cells and increase the pores of the cell wall, the diffusion process is improved, leading to enhanced mass transfer into the solvent [22]. The time factor also is very important when using the sonication technique to extract the phenolic compounds. A longer extraction time allows more contact time for the cavitation bubbles to break more plant cells, resulting an increase of the extracted of phenolic compounds [23].

Phenolic compounds are powerful antioxidants and act in a structure-dependent manner; they can scavenge reactive oxygen species (ROS) and chelate transition metals which play vital roles in the initiation of deleterious free radical reactions [24]. Clearly, the total phenolic content is considered as an important indication of antioxidant properties of natural product extracts. Crude extracts of fruits, vegetables, and other natural product materials are rich in phenolic content. TFC was recorded as having the lowest antioxidant activity and the reason is due to the solvent chosen; this is in agreement with a previous study which reported that antioxidant activity of flavonoids depends on the structure and substitution pattern of hydroxyl groups [8]. Porcupines are herbivores and their dietary intake is from tree barks, seeds, twigs, and grasses $[25,26]$. This explains the reason for PB to have a low flavonoid content, as mostly flavonoid content can be found mainly in fruits, vegetables, leaves and is rarely found in bark or twigs [27]. Some of our initial data using different PB revealed that PBs have similar finding in this study where the phenolics content is low and absence of flavonoid content [28]. However, another study using three different types of PB (black, powdered, and grassy) reported black and powdered PB have significant higher amount of phenolic content compared to grassy PB [29]. Additionally, the GCMS profile also revealed main constituents are amino acids found in animal, which further clarified why PB extract have low phenolic and flavonoid content.

Food antioxidants play an important role in the promotion and maintenance of health as the antioxidant capacity is able to reduce the risk for chronic diseases such as cancer and heart disease [30]. ABTS antioxidant assay observed reaction kinetics of specific enzymes to act as electron donor to form the ABTS•+. Meanwhile, DPPH is a stable free radical and it receives an electron or hydrogen radical to become a stable diamagnetic molecule which is widely used to investigate radical scavenging activity. The ABTS and DPPH assays show PB aqueous extract had strong hydrogen-donating capacity. The results are in agreement with the phenol contents determined for each sample. Antioxidant agents act as reducing agents and antioxidants by the hydrogen-donating property of their hydroxyl groups [31]. The method is influenced by the solvent and the $\mathrm{pH}$ of the reactions.

Therefore, it can be concluded here that the extraction of plants is related to its polarity of extraction solvent used. A previous study has reported that pentadecyl acrylate has DPPH and ABTS antioxidant activity [32]. Another study described ursodeoxycholic acid as having high capacity to scavenge hydroxyl and lipid peroxidation antioxidant assays [33]. Another study conducted antioxidant evaluation using three different types of bezoar namely black, grassy and powdered PB revealed that all three types of PB have different antioxidant capacity in 2, 2-diphenyl-1-picrylhydrazyl free radical scavenging activity assay (DPPH), ferric reducing power assay (FRAP), intracellular reactive oxygen species scavenging activity assay (ROS), and reactive nitric oxide scavenging activity assay [29]. However, the grassy PB displayed the lowest antioxidant activity. 
The cytotoxic assay revealed low concentrations for PB aqueous extract to inhibit 50\% of A375 cell growth at $72 \mathrm{~h}$. The cytotoxic study also suggested that PB exhibited cytotoxic and cytostatic capacity in a dose- and time-dependent manner. However, the flow cytometry analysis revealed PB did not cause cell cycle arrest but exhibited apoptosis. Annexin V/7AAD assay evaluated the cells and categorized them into a quadrant base in the presence or absence of phosphatidylserine and 7-AAD, which helped in differentiating early, late apoptotic and necrotic cells [34]. The PB aqueous extract was revealed to induce apoptosis when compared to UT cells and 5-FU treated cells. The underlying mechanism of apoptosis induction revealed PB aqueous extract exhibited apoptosis via mitochondria apoptosis pathway. The intrinsic pathway is initiated within cells involving the Bcl2 families such as pro-apoptosis (Bax) and anti-apoptosis (Bcl2) genes to regulate the promotion or inhibition of apoptosis [35,36]. PB aqueous extract also found to up-regulate the expressions of cytochrome $C$, caspase 9 , and caspase 3 . The finding was found to be in line with the intrinsic pathway in which internal stimuli induce bax to activate cytochrome $\mathrm{C}$ release into cytosol and activate caspase cascade through caspase 9 and caspase $3[37,38]$. The GCMS analysis revealed two compounds detected from PB aqueous extract possessed anticancer activity, namely stearic acid and ursodeoxycholic acid. Stearic acid is an 18-carbon chain of fatty acid found primarily in animal derivatives and plant fat [39]. Stearic acid has earlier been reported to induce apoptosis in MDA-MB-231 through mitochondria pathway by reducing mitochondria membrane potential, which leads to the release of cytochrome c into cytosol $[40,41]$. Ursodeoxycholic acid described to exhibit anticancer properties by inhibiting cell proliferation through regulation of oxidative stress in colon cancer cells [42]. However, remaining compounds are yet to be explored for their biological potential.

The bezoars are formed from the reaction of undigested porcupine food and enzymes from porcupine itself. The bezoar itself is a medical illness (gastrolith) for porcupines and needs to be surgically removed for the porcupine to survive. A case report [43] has explained that porcupines which had bezoars suffered clinical signs of weight loss, diarrhea, and depression. Ignoring the condition leads to death as the bezoar causes gastric perforation. Additionally, it is crucial to understand that each PB is unique in each porcupine. The chemical profile of each PB depends on the food habits of individual porcupine; the age of the bezoar in the porcupine and the location of the bezoar collected could also play major roles in the different chemical profiles of the bezoar.

\section{Conclusions}

The findings in this study have reported PB aqueous extract's chemical profile, antioxidant activity, and anticancer activity on A375 cells for the first time. PB aqueous extract revealed 5,10-diethoxy-2,3,7,8-tetrahydro-1H,6H-dipyrrolo [1, 2-a: 1', 2'-d] pyrazine, ursodeoxycholic acid, cholest-5-en-3-ol (3.beta.)-, carbonochloridate, and pentadecyl acrylate as the major constituents. The compounds that may be responsible for the anticancer activity of PB aqueous extract are ursodeoxycholic acid and stearic acid. However, other unidentified compounds which were not present in the library of the GC-MS system may also play some roles towards its antioxidant and anticancer effects. The PB showed low TPC and TFC values, which play major roles in the antioxidant activity (ABTS $>$ DPPH $>\beta$-carotene). $\mathrm{PB}$ extract was shown to inhibit cell growth through induction of apoptosis via the mitochondria pathway with minimal toxicity to NHDF cells. However, further study is still necessary to isolate active compounds of PB and evaluate their antioxidant and anticancer properties along with safety profile.

Supplementary Materials: The following are available online at http://www.mdpi.com/2076-3921/8/2/39/s1. Table S1: Primers for gene expression; Figure S1: Structure and mass spectrum of components of porcupine bezoar extract; Figure S2: Standard curve total phenolic content of gallic acid; Figure S3: Standard curve total flavonoid content of quercetin.

Author Contributions: F.A.A. performed the extraction, total phenol content (TPC), total flavonoid content (TFC), and bioautography assays. A.Y.F.K. performed the characterization, anticancer effect, and statistical analysis. M.F.J. and H.A.N. guide the statistical analysis. T.K.J. and A.Y.F.K. wrote the article. F.O.R. and Q.U.A. contributed in guiding F.A.A. and A.Y.F.K. R.A.W. planned and supervised the overall study. 
Funding: Authors would also like to thank and acknowledge the Ministry of Higher Education (MOHE), Malaysia for funding this research to accomplish through FRGS 13-055-0296 and FRGS 16-045-0544.

Acknowledgments: Special thanks to the Department of Wildlife and National Parks Malaysia for granting an approval to conduct this study at IIUM and appreciation to Dato' Ridzwan Hashim for giving the idea in initiating the porcupine bezoar research.

Conflicts of Interest: The authors declare no conflict of interest.

\section{References}

1. Siegel, R.; Miller, K.; Jemal, A. Cancer statistics, 2015. CA Cancer J. Clin. 2015, 65, 29. [CrossRef] [PubMed]

2. Hajjar, D.; Kremb, S.; Sioud, S.; Emwas, A.H.; Voolstra, C.R.; Ravasi, T. Anti-cancer agents in Saudi Arabian herbals revealed by automated high-content imaging. PLoS ONE 2017, 12, e0177316. [CrossRef] [PubMed]

3. Chinembiri, T.N.; Gerber, M.; du Plessis, L.; du Preez, J.; du Plessis, J. Topical Delivery of 5-Fluorouracil from Pheroid $^{\mathrm{TM}}$ Formulations and the In Vitro Efficacy Against Human Melanoma. AAPS PharmSciTech 2015, 16, 1390-1399. [CrossRef] [PubMed]

4. Duvoix, A.; Blasius, R.; Delhalle, S.; Schnekenburger, M.; Morceau, F.; Henry, E.; Dicato, M.; Diederich, M. Chemopreventive and therapeutic effects of curcumin. Cancer Lett. 2005, 223, 181-190. [CrossRef] [PubMed]

5. Cragg, G.M.; Newman, D.J. Plant as source of anticancer agents Plants as a source of anti-cancer agents. J. Ethnopharmacol. 100 2014, 100, 72-79. [CrossRef] [PubMed]

6. Pisoschi, A.M.; Negulescu, G.P. Methods for Total Antioxidant Activity Determination: A Review. Biochem. Anal. Biochem. 2012, 1, 1-10. [CrossRef]

7. Khurana, R.K.; Jain, A.; Jain, A.; Sharma, T.; Singh, B.; Kesharwani, P. Administration of antioxidants in cancer: debate of the decade. Drug Discov. Today 2018, 1-8. [CrossRef] [PubMed]

8. Sharififar, F.; Dehghn-nudeh, G.; Mirtajaldini, M. Major flavonoids with antioxidant activity from Teucrium polium L. Food Chem. 2009, 112, 885-888. [CrossRef]

9. Mori, E.; Sforzi, A. Structure of phytobezoars found in the stomach of a crested porcupine, Hystrix cristata L., 1758. Folia. Zool. 2013, 62, 232-234. [CrossRef]

10. Duffin, C.J. Porcupine Stones. Pharm. Hist. (Lond) 2013, 43, 13-22.

11. Barroso, M.D.S. The Bezoar Stone: A Princely Antidote, The Távora Sequeira Pinto Collection-Oporto. Acta Med. Hist. Adriat. 2014, 12, 77-98.

12. Beaven, L.; Lloyd, K.J. Cardinal Paluzzo Paluzzi degli Albertoni Altieri and his collection in the Palazzo Altieri The evidence of the 1698 death inventory, Part ii. J. Hist. Collect. 2018, 1-16. [CrossRef]

13. Stephenson, M. From Marvelous Antidote to the Poison of Idolatry: The Transatlantic Role of Andean Bezoar Stones during the Late Sixteenth and Early Seventeeth Centuries. Hisp. Am. Hist. Rev. 2014, 90, 1-39. [CrossRef]

14. Duffin, C. Bezoar stones and their mounts. Society of Jewellery Historians 2013, 16, 1-3.

15. Rezaie, M.; Farhoosh, R.; Iranshahi, M.; Sharif, A.; Golmohamadzadeh, S. Ultrasonic-assisted extraction of antioxidative compounds from Bene (Pistacia atlantica subsp. mutica) hull using various solvents of different physicochemical properties. Food Chem. 2015, 173, 577-583. [CrossRef] [PubMed]

16. Javadi, N.; Abas, F.; Hamid, A.A.; Simoh, S.; Shaari, K.; Ismail, I.S.; Mediani, A.; Khatib, A. GC-MS-Based Metabolite Profiling of Cosmos caudatus Leaves Possessing Alpha-Glucosidase Inhibitory Activity. J. Food Sci. 2014, 79, 1130-1136. [CrossRef] [PubMed]

17. Umar, A.; Ahmed, Q.U.; Muhammad, B.Y.; Dogarai, B.B.S.; Soad, S.Z.B.M. Anti-hyperglycemic activity of the leaves of Tetracera scandens Linn. Merr. (Dilleniaceae) in alloxan induced diabetic rats. J. Ethnopharmacol. 2010, 131, 140-145. [CrossRef] [PubMed]

18. Chang, H.; Ho, Y.; Sheu, M.; Lin, Y.; Tseng, M.; Wu, S.; Huang, G.; Chang, Y. Antioxidant and free radical scavenging activities of Phellinus merrillii extracts. Bot. Stud. 2007, 48, 407-417.

19. Shalaby, E.A.; Shanab, S.M.M. Comparison of DPPH and ABTS assays for determining antioxidant potential of water and methanol extracts of Spirulina platensis. Indian J. Geo-Mar. Sci. 2013, 42, 556-564.

20. Dewanjee, S.; Gangopadhyay, M.; Bhattabharya, N.; Khanra, R.; Dua, T.K. Bioautography and its scope in the field of natural product chemistry. J. Pharm. Anal. 2015, 5, 75-84. [CrossRef] 
21. Ilghami, A.; Ghanbarzadeh, S.; Hamishehkar, H. Optimization of the Ultrasonic-Assisted Extraction of Phenolic Compounds, Ferric Reducing Activity and Antioxidant Activity of the Beta vulgaris Using Response Surface Methodology Optimization of the Ultrasonic-Assisted Extraction of Phenolic Compounds. Pharm. Sci. 2015. [CrossRef]

22. Annegowda, H.V.; Bhat, R.; Min-Tze, L.; Karim, A.A.; Mansor, S.M. Influence of sonication treatments and extraction solvents on the phenolics and antioxidants in star fruits. J. Food Sci. Technol. 2012, 49, 510-514. [CrossRef] [PubMed]

23. Liu, C.; Wang, Y.; Lu, H.; Chiang, W. Optimization of ultrasound-assisted extraction conditions for total phenols with anti-hyperglycemic activity from Psidium guajava leaves. Process. Biochem. 2014, 10, 4-8. [CrossRef]

24. Srivastava, S.; Dubey, R. Manganese-excess induces oxidative stress, lowers the pool of antioxidants and elevates activities of key antioxidative enzymes in rice seedlings. Plant Growth Regul. 2011, 64, 1-16. [CrossRef]

25. Akram, F.; Ilyas, O.; Haleem, A. Food and Feeding Habits of Indian Crested Porcupine in Pench Tiger Reserve, Madhya Pradesh, India. Ambient Sci. 2017, 4, 0-5. [CrossRef]

26. Felicetti, L.A.; Shipley, L.A.; Witmer, G.W.; Robbins, C.T. Digestibility, nitrogen excretion, and mean retention time by North American porcupines (Erethizon dorsatum) consuming natural forages. Physiol. Biochem. Zool. 2000, 73, 772-780. [CrossRef] [PubMed]

27. Panche, A.; Diwan, A.; Chandra, S. Flavanoids: An overview. J. Nutr. Sci. 2016, 5, 1-15. [CrossRef]

28. Firus Khan, A.Y.; Asuhaimi, F.A.; Jalal, T.; Natto, H.A.; Roheem, F.O.; Ahmed, Q.U.; Johan, M.F.; Abd Wahab, R. Anti-Proliferative Property of Porcupine Bezoar Extract on Melanoma( A375 ). Int. J. Allied. Heal. Sci. 2017, 1, 1-13.

29. Yew, P.N.; Lee, L.W.L.; Lim, Y.Y. Antioxidant and Intracellular Reactive Oxygen Species/Reactive Nitrogen Species Scavenging Activities of Three Porcupine Bezoars from Hystrix brachyura. Pharmacogenosy Nat. Prod. 2017, 366-372. [CrossRef]

30. Aydemir, S.; De Smet, S.; Miserez, B.; Sandra, P. Antioxidant components of Viburnum opulus L. determined by on-line HPLC-UV-ABTS radical scavenging and LC-UV-ESI-MS methods. Food Chem. 2015, 175, $106-114$. [CrossRef]

31. Schleiden, M.; Carvalho, S.; Cardoso, G.; Resende, L.V.; Gomes, M.D.S.; Roberto, L.; Albuquerque, M.; Cristini, A.; Gomes, S.; Sales, T.A.; et al. Phytochemical Screening, Extraction of Essential Oils and Antioxidant Activity of Five Species of Unconventional Vegetables. Am. J. Plant Sci. 2015, 6, 2632-2639.

32. Huang, B.; Ban, X.; He, J.; Tong, J.; Tian, J.; Wang, Y. Comparative analysis of essential oil components and antioxidant activity of extracts of Nelumbo nucifera from various areas of China. J. Agric. Food Chem. 2010, 58, 441-448. [CrossRef] [PubMed]

33. Lapenna, D.; Ciofani, G.; Festi, D.; Neri, M.; Pierdomenico, S.D.; Giamberardino, M.A.; Cuccurullo, F. Antioxidant properties of ursodeoxycholic acid. Biochem. Pharmacol. 2002, 64, 1661-1667. [CrossRef]

34. Riccardi, C.; Nicoletti, I. Analysis of apoptosis by propidium iodide staining and flow cytometry. Nat. Protoc. 2006, 1, 1458-1461. [CrossRef] [PubMed]

35. Sun, S.-Y.; Hail, N.; Lotan, R. Apoptosis as a novel target for cancer chemoprevention. J. Natl. Cancer Inst. 2004, 96, 662-672. [CrossRef] [PubMed]

36. Al'aina yuhainis, F.K.; Mohd Hamzah, M.N.; Tara, J.; Shakirah, R.; Habibah, H.; Faizah Abdullah, A.; Ridhwan, A.W. In Vitro Evaluation of Porcupine Bezoar Extracts as Anticancer Agent on A549 -A Preliminary Study. Adv. Biotechnol. Microbiol. 2017, 5, 1-8. [CrossRef]

37. Song, X.; Li, Y.; Zhang, H.; Yang, Q. The anticancer effect of Huaier (Review). Oncol. Rep. 2015, 34, $12-21$. [CrossRef]

38. Hengartner, M.O. The biochemistry of apoptosis. Nature 2000, 407, 770-776. [CrossRef]

39. Li, J.; Pan, C.; Yanase, T.; Nawata, H. Saturated free fatty acids, palmitic acid and stearic acid, induce apoptosis by stimulation of ceramide generation in rat testicular Leydig cell. Biochem. Biophys. Res. Comm. 2003, 303, 1002-1007. [CrossRef]

40. Evans, L.M.; Cowey, S.L.; Siegal, G.P.; Hardy, R.W. NIH Public Access. Nutr. Cancer 2010, 61, 746-753. [CrossRef]

41. Hardy, S.; El-assaad, W.; Przybytkowski, E.; Joly, E.; Prentki, M.; Langelier, Y. Saturated Fatty Acid-induced Apoptosis in MDA-MB-231 Breast Cancer Cells. J. Biol. Chem. 2003, 278, 31861-31870. [CrossRef] [PubMed] 
42. Kim, E.; Cho, J.H.; Kim, E.; Kim, Y.J. Ursodeoxycholic acid inhibits the proliferation of colon cancer cells by regulating oxidative stress and cancer stem-like cell growth. PLoS ONE 2017, 12, e0181183. [CrossRef] [PubMed]

43. Spriggs, M.; Thompson, K.A.; Barton, D.; Talley, J.; Volle, K.; Stasiak, I.; Beyea, L.; Guthrie, A.; Roda, A.; Camborata, C.; et al. Gastrolithiasis in Prehensile-Tailed Porcupines (Coendou prehensilis): Nine Cases And Pathogenesis of Stone Formation. J. Zoo. Wildl. Med. 2014, 45, 883-891. [CrossRef] [PubMed]

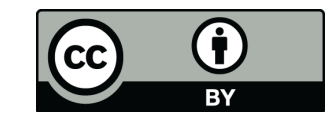

(C) 2019 by the authors. Licensee MDPI, Basel, Switzerland. This article is an open access article distributed under the terms and conditions of the Creative Commons Attribution (CC BY) license (http:/ / creativecommons.org/licenses/by/4.0/). 